\title{
An Exploration on Designing College English Listening Class
}

\author{
Hongyu Wang \\ Capital University of Economics and Business, Beijing 100070, China \\ Email: wendyhongyu@163.com
}

\begin{abstract}
Teaching listening, rather than "pushing button English" and testing later, involves a change in pattern, application of listening strategies, approaches application, and a variety of materials. Teaching listening will be going through three stages of classroom activities to help students to foster ability to understand and take notes on listening material-before, while and after listening. Extended post-listening after class autonomously is more fruitful in helping learners' problems identified and tackled so as to improve students' listening skill and strengthen students' learning effect in listening class.
\end{abstract}

Index Terms - listening strategies and techniques, listening teaching mode, three stages

\section{INTRODUCTION}

\section{A. Current Situation}

In recent years, a wide phenomenon in universities is that a considerable number of English teachers in universities simply push the button to play the tape or CD several times for students to get input and then do exercises related in English listening class. It is so called "Push Button English". They still maintain that in listening class they are under less pressure compared to integrated course. However, listening class is not simply designed as "Push Button English", and doing exercises later. It is designed not only to construct knowledge through listening but to improve listening skills and strategies for future use as well. Applying listening strategies to teaching practice in listening class does benefit students for future study. However, only a small number of teachers adopt listening strategies and foster students' skills by training them on purpose in class. Mendelsohn (1995) stressed that "A strategy-based approach teaches learners to listen effectively by instructing them in the use of strategies" (p.134). Teaching listening will be going through three stages of classroom activities to develop students' ability to understand and take notes on listening material — before, while and after listening (Lynch, 2004).

\section{B. New Challenge}

According to a Fortune 500 CEO Survey of CEO's, they are looking today for employees who are:

1. Global thinkers

2. Excellent communicators

3. Team workers

4. Innovative

5. Creative

6. Cooperative

7. Problem solvers

8. Independent

9. Self-starters

10. Technologically competent

So international talents are intended to possess the following qualities: widened global perspective, structure of specialized global knowledge, familiar with international rules, competence in cross-cultural communication in foreign language, independent ability for global organization, capability to use and tackle foreign information, and higher order political thinking and healthy psychology as well. In order to achieve this goal, students are supposed to be familiar with the learning process of acquiring knowledge and skills in English listening class: 
THE LEARNING PYRAMID:

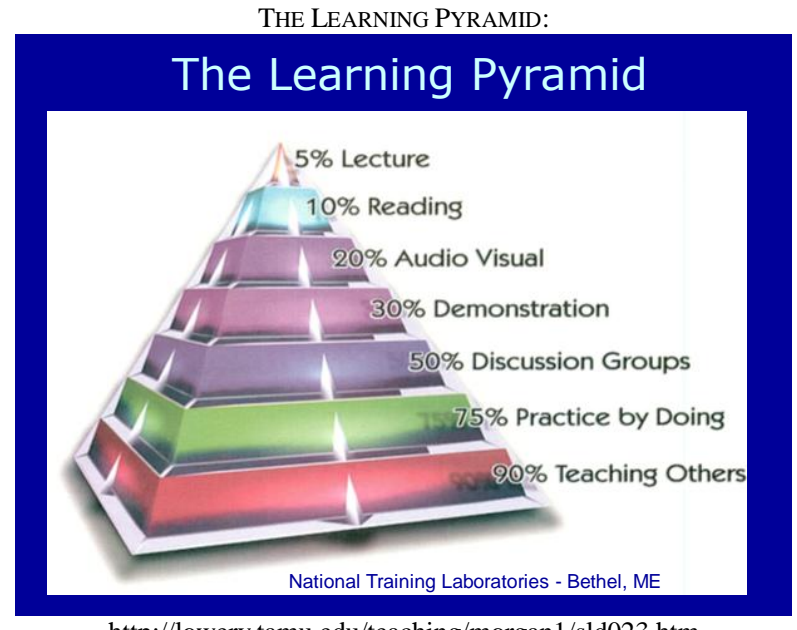

http://lowery.tamu.edu/teaching/morgan1/sld023.htm

From this learning pyramid, students will know what they should do to acquire English knowledge and skills in order to achieve the learning target well in class.

\section{Teaching Mode In Listening Class}

Traditionally, the listening pattern in class is passive just as many teachers still carry on in their classes now. However bottom-up, top-down, interactive, and task-based methods are advocated and applied by more and more English teachers to achieve listening comprehension and develop communication skills. As cited in Zhang and Zhu (2004) research has shown that in general good listeners use a variety of metacognitive, cognitive, social and affective strategies and strategy instruction does help improve listening comprehension. (Cohen, 1990; Chamot, 1993; O'Malley \& Chamot, 1990). So careful strategy-based teaching helps learners bring listening to a conscious level. Before teaching listening, diagnosing students' listening problems is indispensable. Qu \& Jiang (1998) argued that "Eight factors have been often discussed. They are motivation, intelligence, aptitude, attitude, personality, age first language, and learning strategies" (p.5). Particularly, the students' levels, their needs, interests, listening style, personality, background, ability, and expectations. So a placement test and "troubleshooting", is a priory in order to identify students' particular problems. Secondly, a syllabus design is followed mainly for the teacher to carry on teaching and solve the students' problems according to their needs.

Furthermore, especially in listening class, using a Communicative Language Teaching Approach is challenging but beneficial. Mark (2005) argued Communicative Language Learning that relies exclusively on communication tasks without language awareness is not effective. A method that concentrates on language analysis without communicative language practice and tasks is equally ineffective. An eclectic method that combines communication and language awareness study is consistent with what we know about the functioning of the brain and how human beings learn, and it is effective.

\section{A. Before Listening}

Top-down approach is attached to much more importance in predicting information, brainstorming ideas in a form of mind map, focal points of vocabulary on the blackboard, warm-up activities are often used to help students to guess what will be going on next and prepare students to establish a link between old knowledge and new information. As Lynch stated "Study listening stimulates that real-life situation through pre-listening discussion, which helps you to call up the background knowledge and relevant language in preparation for what the lecturer says." (Lynch, 2004, p.5)

Cortazzi and Jin (1996) introduced the notion of culture of learning to explain the difference in behaviour in language classrooms. They maintain that a culture of learning has its roots in the educational and, more broadly, cultural traditions of the society, and that the 'Western and Chinese cultures of learning sometimes weave past each other without linking'. (p.10). The way to establish a bridge between the different cultures is through dialogue. Thus, cultural background introduction before listening is essential according to "schema theory" which is based on the notion that past experiences lead to the creation of mental frameworks that help us make sense of new experiences. It focuses on two ways of decoding information: from "bottom-up" to "top-down". Shu (2009) pointed out "If the teacher suspects that there are gaps in students' knowledge, either of content or of grammar or vocabulary, the listening itself can be preceded by schema-building activities". (p.118)

\section{B. While Listening}

Shu (2009) emphasized "traditionally, in language teaching, listening comprehension used to be thought of as a passive skill. Like reading, listening comprehension is now no longer regarded as a passive skill. The decoding of a message calls for active participation in communication between participants". (p.133) Listening comprehension is an 
interactive process involving active guessing, approximation, expectation, idealization which makes extensive use later in a typical speech. After the initial reception of the sound, students perform several operations, such as processing the "raw material" and holding an image in short-term memory; determining the speech event; inferring the objectives of the speaker; recalling background information; assigning a literal meaning or an intended meaning, etc. Thus, Bottom-up and interactive processes are significant. First listening is extensive. Students should be told to get a global understanding of the listening material by doing multiple choice questions like "Who", "When", Where", "What", "How" etc. to guide students to construct general meanings. Second listening is intensive process. Making notes shorter but effective is of great importance. Different, clear tasks are assigned to different groups of students based on their level and ability. For example, guessing key words from the context, detailed note-taking of key points, summarizing the main ideas is given to different students who are supposed to work out answers by collaborative efforts through comparing of notes, checking answers, arguing with each other, etc so as to make the whole process interactive. In this way, listening becomes a much more interactive activity with listeners listening not because the teachers tell them to, but they have a vested interest in justifying their own explanation of the text. By means of listening and re-listening, they improve the accuracy and by discussing possible interpretations, they improve their ability and construct representations of meaning from what they hear. In the whole process, taking notes is indispensable. However, As Lynch (2004) stressed combining, listening and writing is not easy, even in our first language, so techniques for making notes shorter but effective is essential, which are as followed:

\section{Note-taking Techniques}

Note-taking is very personal and there is no single best system in class.

First listening-general

1. Guided note-taking for main ideas and development

2. Focus on relevant macrostrategy

3. Oral summary

Second listening-specific

1. Detailed note-taking

2. Comparison of note-taking

According to Lynch, note-taking is very personal and there is no single best system. But there are three basic rules that enable note-taking quicker and more effective.

1. Be selective: decide what is important;

2. Be brief: use abbreviations, initials, official abbreviations, and symbols;

3. Be clear: show the interrelationship between the speaker's points (linear notes; mind map, spider notes or web notes)

Stevens, F. (1976) argues that although students in the activity-centered program used the target language for only $40 \%$ of the school day, they attained the same levels of target language speaking and reading proficiency and almost the same levels of proficiency as the students in the teacher-centered program, which provided all instruction in the target language.

\section{After Listening}

Focus on language and content should be emphasized. Students are expected to identify functional language such as apologizing, inviting, refusing, suggesting, and so no, and help listeners to achieve lexical segmentation. Moreover, inferring the meaning of new words is required too. Post-listening is endless work. As the old saying goes "Practice makes perfect." Students should do a lot of relevant and selective practice autonomously after class in order to be proficient in listening comprehension.

In addition, authentic listening materials from $\mathrm{BBC}, \mathrm{VOA}, \mathrm{CIR}, \mathrm{CNN}$ etc has been increasingly used and is strongly advisable to introduce in EFL listening class in universities in China in that they reflect a natural rhythm of speed of language and provide an experience of something like real-life listening.

\section{SUGGESTED Listening ACTIVITIES}

1. schema-building activities: cultural background, language introduction and predicting information

2. visual - relying more on the sense of sight and learn best through visual means (e.g., books, video, movie appreciation, charts, pictures)

3. auditory - preferring listening and speaking activities (e.g., discussions, debates, audiotapes, role-plays, lectures).

4. hands-on - benefiting from doing projects, working with objects and moving around. (movie dubbing)

5. extroverted - enjoying a wide range of social, interactive learning tasks (e.g., games, conversations, debates, role-plays, simulations)

6. note-taking (taking short-hand such as numbers, figures, names, key words etc.)

7. Lynch (2004) pointed out four stages should be carried for a typical unit. 


\begin{tabular}{|l|l|}
\hline A typical unit & Teaching activities \\
\hline Before listening & 1) topics lead-in \\
& 2) brainstorm information \\
& 3) present new words and difficult grammar \\
\hline Listening for the first time & 1) take guided notes for relevant information and content development \\
& 2) focus on related macrostrategies \\
& 3) oral summary \\
\hline Listening for the second time & 1) detailed note-taking \\
& 2) comparing notes with others in content and note-taking forms \\
\hline Post listening & 1) language focus \\
& a) identifying problems such as speed, accent etc. \\
& b) make marks in the script like intonation stress, pause, fast speed \\
& c) concentrate on forms of note-taking, e.g. comments and the importance of marks-making \\
& 2 content focus \\
& a) clarifying content \\
& b) reflecting critically \\
& c) personal response \\
d) optional extended tasks and essay writing
\end{tabular}

TABLE:

STUDENTS' SCORE IN LISTENING BETWEEN EXPERIMENTAL GROUP AND CONTROL GROUP, APPLYING STRATEGIES BEFORE AND AFTER

\begin{tabular}{|l|l|l|l|l|l|l|l|l|l|}
\hline \multicolumn{2}{|c|}{} & \multicolumn{2}{l|}{ Measures of central tendency } & \multicolumn{2}{l|}{ Measures of dispersion } \\
\hline Group & Mean & mode & Median & minimum & maximum & Range & Standard variation \\
\hline \multirow{2}{*}{$\begin{array}{l}\text { Experimental } \\
\text { Group }\end{array}$} & before & 12.87 & 13 & 13 & 4 & 20 & 16 & 2.65 \\
\cline { 2 - 10 } \\
\cline { 2 - 10 } $\begin{array}{l}\text { Control } \\
\text { Group }\end{array}$ & after & 13.31 & 14 & 12 & 5 & 18 & 13 & 2.66 \\
\cline { 2 - 10 }
\end{tabular}

As is shown, the scores of the experimental group are higher than the control group but it is not obvious. It is evident that students' listening ability is improved through the experiment of applying listening strategies.

\section{CONCLUSION}

Teaching listening, rather than pushing button English and testing later, involves a change in pattern, approaches application, and a variety of materials. Extended post-listening is more fruitful in helping learners' problems identified and tackled. It is of vital importance that our students be taught effectively and critically. First, choose authentic and appropriate listening material; secondly, teach listening skills and strategies; thirdly, foster students' abilities by means of extended listening, reflecting, and reconstructing understanding; finally, cultivate a good environment for improving listening skills both in class and after class. Popkewitz and Wehlage (1973) argued that teaching should be viewed as a craft that includes a reflective approach toward problems, a cultivation of imagination, and a playfulness toward words, relationships, and experiences. The principles of designing listening are: definite goals, careful step-by-step planning, active overt students' participation and involving, communicative urgency, conscious memory work, feedback process, without too much writing, realistic and practical activities, schema-building tasks, and strategies for effective listening as well. Here are some useful tips for listening practice teacher before going into the classroom:

1. Never go into listening without full preparation.

2. Never ask students to memorize in class.

3. Don't worry about every unfamiliar word.

4. Never give students the tapescript.

5. Don't play the tape more than three times

6. Never ask students to write too much while listening.

\section{REFERENCES}

[1] Chamot, A. U. (1993). Students Responses to Learning Strategy Instruction in the Foreign Language Classroom. Foreign Language Annals 26/3: 308-321.

[2] Cohen, A. D. (1990). Language Learning: Insights for Learners, the Teacher, and Researchers. Boston: Heinle \& Heinle.

[3] Lowe, Mark. (2005). The shibboleths of TEFL: Sense and nonsense in language teaching. Modern English Teacher, January, 2005.

[4] Mendelsohn, D. (1995). Applying learning strategies in the second/foreign language listening comprehension. In D. Mendelsohn \& J. Rubin (Eds.), A Guide for the Teaching of Second Language Listening. San Diego, CA: Dominie Press.

[5] M Cortazzi \& L Jin. (2008). Language teaching. Cambridge University Press.

[6] O'Malley, J. M. \& Chamot, A. U. (1990). Learning Strategies in Second Foreign Language Acquisition. Cambridge, England: Cambridge: Cambridge University Press.

[7] Qu Guiju \& Jiang Huijuan. (1998). College English and its Learning Strategies. Teaching English in China Issue32:5.

[8] Shu Baimei. (2009). Modern Foreign Language Teaching Methodology (2ed), Shanghai: Shanghai Foreign Language Education Press.

[9] Stevens, F. (1976). Second language learning in an activity-centered program. Unpublished master's thesis, Concordia 
University.

[10] Thomas S. Popkewitz and Gary G. Wehlage. (1973). Interchange: Accountability: Critique and Perspective, Volume4, No.4, 48-62 DOI: 10.1007/BF02138362, University of Wisconsin.

[11] Tony lynch. (2004). Listening-A Course in Listening to Lectures and Note-taking. Cambridge: Cambridge University Press.

[12] Zhang Zaihong \& Zhu Yuezhen. (2004). Adopting A Strategy-Based Approach To Teaching Listening Comprehension. CELEA Journal Vol.27 No.5

Hongyu Wang was born in Beijing, China in 1966. Se received her M.A. degree in education from Flinders University, Australia in 2007.

She is currently an ASSOCIATE PROFESSOR in Capital University of Economics and Business, Beijing, China. Her research interests include applied linguistics, teaching strategies and British-American literature.

Ms. Wang is an oral examiner of Cambridge Young Learners, Pets and CET4/6. 